\title{
Appendicular skeleton and dermal armour of the Late Cretaceous titanosaur Lirainosaurus astibia (Dinosauria: Sauropoda) from Spain
}

\author{
Verónica Díez Díaz, Xabier Pereda Suberbiola, \\ and José Luis Sanz
}

\begin{abstract}
Lirainosaurus astibiae is the best-known titanosaurian sauropod species from the Iberian Peninsula. It was described by Sanz and collaborators in 1999 on the basis of several cranial and postcranial remains from the Late Cretaceous of Laño (northern Spain); new remains from this and other Iberian fossil-sites have recently been referred to this species. This paper focuses on the description of the appendicular skeleton and dermal armour of Lirainosaurus. Comparison with other European titanosaurs confirms that Lirainosaurus astibiae clearly differs from them, and highlights two diagnostic appendicular features: the presence of a dorsal prominence together with a ventral ridge on the medial surface of the scapular blade, and the combination of an anterolateral process and an anteroventral ridge on the sternal plate. Equations for predicting body mass and size in sauropods suggest a body size up to 6 meters and a body mass of at least 2-4 tonnes for the largest individuals of Lirainosaurus astibiae, it being one of the most slender titanosaurs found to date. The study of the non-axial postcranial skeleton supports the hypothesis that Lirainosaurus astibiae is a derived lithostrotian close to Saltasauridae.
\end{abstract}

Verónica Díez Díaz. Universidad del País Vasco/Euskal Herriko Unibertsitatea, Facultad de Ciencia y Tecnología, Apdo. 644, 48080 Bilbao, Spain. diezdiaz.veronica@gmail.com

Xabier Pereda Suberbiola. Universidad del País Vasco/Euskal Herriko Unibertsitatea, Facultad de Ciencia y Tecnología, Apdo. 644, 48080 Bilbao, Spain. xabier.pereda@ehu.es José Luis Sanz. Universidad Autónoma de Madrid, Facultad de Ciencias, Dpto. Biología, Ud. Paleontología, 28049 Cantoblanco, Madrid, Spain. dinoproyecto@gmail.com

Keywords: Lirainosaurus; Titanosauria; appendicular skeleton; dermal armour; Spain; Upper Cretaceous

Díez Díaz, Verónica, Pereda Suberbiola, Xabier, and Sanz, José Luis. 2013. Appendicular skeleton and dermal armour of the Late Cretaceous titanosaur Lirainosaurus astibiae (Dinosauria: Sauropoda) from Spain, Palaeontologia Electronica Vol. 16, Issue 2; 19A; 18p; 


\section{INTRODUCTION}

Lirainosaurus astibiae is a titanosaurian sauropod from the Late Cretaceous of Laño (northern Spain), first described by Sanz et al. (1999). In fact, it is the best-known titanosaur from the Iberian Peninsula. In recent years, several papers have been produced with a revised description of the published material, as well as new remains referred to this titanosaur, i.e., new cranial specimens such as a braincase (Díez Díaz et al., 2011) and a large sample of teeth that show ontogenetic variation (Díez Díaz et al., 2012). Postcranial remains from other Spanish localities have also been referred to Lirainosaurus (Company et al., 2009; Ortega and Pérez-García, 2009).

Lirainosaurus astibiae has been included in approximately 16 phylogenetic analyses to date, and in most of them it appears as a derived member of Lithostrotia or closely related to Saltasauridae (e.g., Sanz et al., 1999; Powell, 2003; Upchurch et al., 2004; Calvo et al., 2007; González Riga et al., 2009; Hocknull et al., 2009).

Knowledge of the axial skeleton of Lirainosaurus astibiae has also been increased, thanks to a detailed study of the vertebral laminae and fossae in the axial series as well as the inclusion of new vertebral remains in its description (Díez Díaz et al., 2013). In this paper, we proceed to describe the appendicular skeleton and dermal armour of this Iberian titanosaur, including all the known girdle elements, limb bones and osteoderms. In addition, comparisons are made between Lirainosaurus and other titanosaurians, mainly the European forms.

All this previous work and the detailed description of the material (Sanz et al., 1999; Company et al., 2009; Company, 2011; Díez Díaz et al., 2011, 2012, 2013, this paper), as well as its inclusion in numerous phylogenetic analyses, have made Lirainosaurus astibiae one of the world's best-known titanosaurian species, and a main reference for the study of the sauropod faunas of the Late Cretaceous of Europe.

\section{GEOLOGICAL SETTING}

The Laño quarry is located between the villages of Laño and Albaina in the Condado de Treviño, an enclave of the province of Burgos that lies within Alava in the Basque Country, in the north of the Iberian Peninsula (Figure 1). From a geological point of view, Laño and the adjacent region lie within the Sub-Cantabrian Synclinorium in the southeastern part of the Basque-Cantabrian Region (Baceta et al., 1999). Laño has yielded a

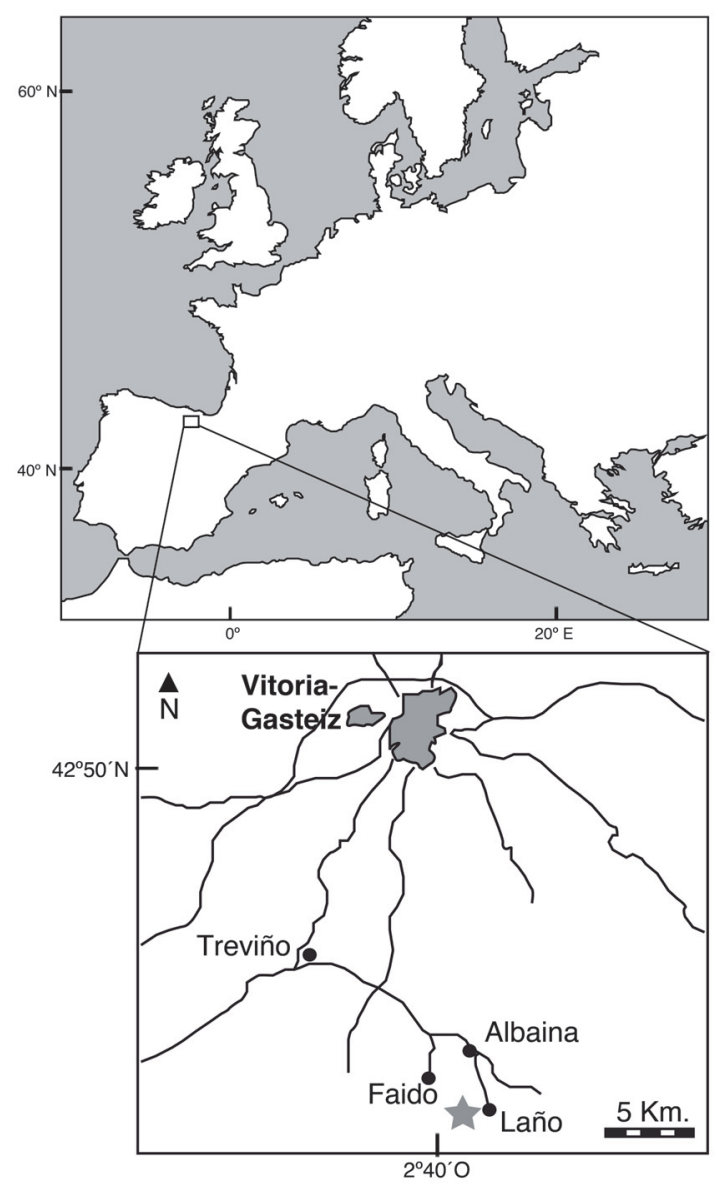

FIGURE 1. Map showing the geographic location of the Laño quarry.

diverse continental vertebrate assemblage of Late Cretaceous (probably late Campanian to early Maastrichtian) age, including fossil remains of bony fish, amphibians, lizards, snakes, turtles, crocodilians, pterosaurs, dinosaurs and mammals (Astibia et al., 1990, 1999; Pereda Suberbiola et al., 2000). The continental fossiliferous beds (L1A, L1B and L2) of the Laño quarry were deposited in an alluvial system composed primarily of fluvial sands and silts. The sedimentary structures are consistent with channel areas within an extensive braided river (Astibia et al., 1990, 1999).

\section{MATERIAL AND METHODS}

For the anatomical structures we use "Romerian" terms (Wilson, 2006) for their orientation (e.g., "anterior", not "cranial"). Osteological descriptions are organized as follows: pectoral girdle, forelimb, pelvic girdle, hind limb and osteoderms. The eccentricity index (ECC) has been calculated for both humeri and femora as the mid-shaft mediolat- 
eral width divided by the anteroposterior width (Wilson and Carrano, 1999). The robustness index (RI) has been calculated for all the appendicular remains as the average of the greatest widths of the proximal and distal ends and the mid-shaft divided by the length of the element in question (Wilson and Upchurch, 2003). For the body mass and size we have used the equations proposed by Packard et al. (2009), Seebacher (2001) and Campione and Evans (2012), in which $\mathrm{M}(\mathrm{g})=$ 3.352 $\mathrm{Per}_{\mathrm{H}+\mathrm{F}^{2}}{ }^{2125}, \mathrm{M}(\mathrm{kg})=214.44 \mathrm{~L}(\mathrm{~m})^{1.46}$, and $\log \mathrm{M}(\mathrm{g})=2.754 \log \mathrm{Per}_{\mathrm{H}+\mathrm{F}}-1.097$, where $\mathrm{M}$ : body mass, $\operatorname{Per}_{\mathrm{H}+\mathrm{F}}$ : sum of the perimeters of the humerus and femur in $\mathrm{mm}$, L: body length.

Comparison of the appendicular skeleton of $L$. astibiae will mainly be with the European titanosaurian taxa described until now: Ampelosaurus atacis from Campagne-sur-Aude (Aude, France) (Le Loeuff, 1995, 2005), Atsinganosaurus velauciensis from Velaux (Bouches-du-Rhône, France) (Garcia et al., 2010), Paludititan nalatzensis from NalatVad (Hateg Basin, Romania) (Csiki et al., 2010), and the material from the Hateg Basin (Romania) referred to Magyarosaurus dacus housed in the Natural History Museum (London, U.K.). A comparison is also made with the material of Lirainosaurus cf. astibiae from Chera (Valencia, Spain) (Company et al., 2009). All the comparisons, except for $P$. nalatzensis, are based on first-hand observations by the senior author (V.D.D.). Several comparisons have been made with other titanosaurs on the basis of important taxonomical and phylogenetic features that will help to distinguish Lirainosaurus and the other European taxa from the titanosaurs of the rest of the world.

Institutional Abbreviations. NHMUK, Natural History Museum, London, U.K.; MCNA, Museo de Ciencias Naturales de Álava/Arabako Natur Zientzien Museoa, Vitoria-Gasteiz, Spain; MDE, Musée des Dinosaures, Espéraza, France; MGUV, Museo de Geología de la Universidad de Valencia, Burjassot, Spain.

\section{SYSTEMATIC PALEONTOLOGY (TABLE 1)}

DINOSAURIA Owen, 1842

SAURISCHIA Seeley, 1887

SAUROPODA Marsh, 1878

TITANOSAURIA Bonaparte and Coria, 1993

LITHOSTROTIA Upchurch et al., 2004

Lirainosaurus astibiae Sanz et al., 1999
TABLE 1. Appendicular skeleton and dermal armour, MCNA collection.

$\begin{array}{ll}\text { Scapulae } & \text { MCNA 7459, 13855, 14461, 14462 } \\ \text { Coracoids } & \text { MCNA 1846, 3158, 7460 } \\ \text { Sternal plate } & \text { MCNA 7461 } \\ \text { Humeri } & \text { MCNA 7462-7465, 14463 } \\ \text { Ulna } & \text { MCNA 3157 } \\ \text { Ilia } & \text { MCNA 7456, 8609, 13861, 14464 } \\ \text { Pubis } & \text { MCNA 7467 } \\ \text { Femora } & \text { MCNA 1817, 3160, 7468, 14465-14468 } \\ \text { Tibiae } & \text { MCNA 2203, 7471, 13860, 14469, } \\ \text { Fibulae } & \text { MC470 } \\ \text { III Metatarsal } & \text { MCNA 14474 } 7410,14471 \\ \text { Osteoderms } & \text { MCNA 14473, 14474 }\end{array}$

Holotype. MCNA 7458, anteriormost caudal vertebra (Sanz et al., 1999: pl. 2; Díez Díaz et al., 2013: fig. 4).

Paratypes. an incomplete braincase (MCNA 7439), two isolated teeth (MCNA 7440, 7441), ten dorsal vertebrae (MCNA 7442-7450, 7456), seven caudal vertebrae (MCNA 1812, 7451-7457), one scapula (MCNA 7459), one coracoid (MCNA 7460), one sternal plate (MCNA 7461), four humeri (MCNA 7462-7465), a fragment of ilium (MCNA 7466), a fragment of a pubis (MCNA 7467), three femora (MCNA 3160, 7468, 7470), a tibia (MCNA 7471), a fibula (MCNA 7472) and two osteoderms (MCNA 14473, 14474) (figured in Sanz et al., 1999).

Referred Material (see also Díez Díaz, 2013). MCNA 13913, an incomplete braincase (Díez Díaz et al., 2011), numerous teeth (MCNA 1854, 12402, 13866-13878, 13914, 14231-14239 figured in Díez Díaz et al., 2012), a cervical centrum (MCNA 14429), 16 dorsal vertebrae and vertebral remains (MCNA 1816, 1818, 1883, 3159, 8551, 8604, $8608,13852,13856,13858,13859,14430-14434)$, 35 caudal vertebrae (MCNA 1882, 2207, 2208, 2211, 7458, 8605-8607, 9647, 13388, 13851, $13853,13854,13857,14435-14455)$, four rib remains (MCNA 14456-14459), a haemal arch (MCNA 14460) (the axial skeleton is figured in Díez Díaz et al., 2013), three scapulae (MCNA 13855, 14461, 14462), two coracoids (MCNA 1846, 3158), a humerus (MCNA 14463), an ulna (MCNA 3157), three iliac remains (MCNA 8609, 13861, 14464), five femora (MCNA 1817, 14465-68), four tibiae (MCNA 2203, 13860, 14469), two fibulae (MCNA 9410,14471 ) and one metatarsal III (MCNA 
14474) (the appendicular and dermal skeletons are figured in the present paper).

Revised diagnosis (see also Díez Díaz, 2013; Díez Díaz et al., 2011, 2013). Presence of a foramen in the distal surface of each basal tuber; absence of median subcondylar foramina in the basioccipital, below the occipital condyle and between the basal tubera (this could be an autapomorphic trait or a feature due to ontogenetic growth); presence of a lamina in the interzygapophyseal fossa in the proximal caudal vertebrae (a podl that separates pocdf and posdf); spinopostzygapophyseal structure not posteriorly projected in the posterior caudal vertebrae; medial surface of the scapular blade with a dorsal prominence and sometimes also a ventral ridge; and sternal plate with an anteroventral ridge, an anterolateral process and a concave lateral edge.

Locality and Horizon (Figure 1). Laño quarry, between the towns of Laño and Albaina (Condado de Treviño), Spain; levels L1A, L1B and L2; unit S3U1 of Astibia et al. (1987, 1990); upper zone of unit B of Baceta et al. (1999); unit equivalent to the Sedano Formation of the North-Castilian Platform (Floquet, 1991; Berreteaga, 2008); Upper Cretaceous, probably late Campanian to early Maastrichtian.

Remarks. Lirainosaurus, a small-sized sauropod, is the largest vertebrate in the Laño association (Pereda Suberbiola et al., 2000). Sanz et al. (1999) erected $L$. astibiae on the basis of a fragment of skull, several isolated teeth and a set of postcranial elements. A braincase, a number of additional teeth and several axial remains from Laño have been referred to Lirainosaurus (Díez Díaz, 2013; Díez Díaz et al., 2011, 2012, 2013).

The material of Lirainosaurus astibiae comes from three fossiliferous strata and corresponds to several different individuals. Elements with the same morphology but also with shared autapomorphies, such as caudal vertebrae, iliac fragments and fibulae, have been found in two or in all three beds, strengthening the hypothesis of the presence of a single titanosaurian taxon in Laño. As a whole, the remains of $L$. astibiae found in Laño are quite homogenous and show little osteological variation, indicating that they probably belong to the same species (Sanz et al., 1999; Díez Díaz, 2013; Díez Díaz et al., 2011, 2012, 2013).

Besides Laño, titanosaurian material referred to Lirainosaurus has been described from two other Iberian localities (Company et al., 2009; Ortega and Pérez García, 2009).

\section{DESCRIPTION AND COMPARISONS}

The appendicular skeleton of Lirainosaurus astibiae is represented by pectoral girdle (scapula, coracoid, sternal plate), forelimb (humerus, ulna), pelvic girdle (ilium, pubis) and hindlimb (femur, tibia, fibula, metatarsal) bones. In addition, a few elements from the dermal armour are also known. All elements were recovered as isolated specimens, but some of them were found in close proximity to each other and could belong to the same individual. The measurements of these appendicular bones are detailed in Tables 2-5.

\section{Pectoral Girdle (Figure 2) (Table 2)}

Four scapulae are known: two left (MCNA 7459, 13855), one right (MCNA 14461), and a poorly preserved fragment (MCNA 14462). Three coracoids have been recovered: two right (MCNA 1846, 7460) and one left (MCNA 3158). The scapula MCNA 14461 and the coracoid MCNA 3158 probably belong to the same individual, as they were found close together. Only one right sternal plate is known (MCNA 7461).

Scapula (Figure 2.1-3). The scapulae will be described with the blade oriented horizontally. The best-preserved and largest specimen is MCNA 14461. The acromion is medially curved and concave in its medial surface. The dorsal margin of the acromion is damaged, so it is not possible to infer its total extension to the coracoid articulation. None of the specimens shows an acromial ridge. The glenoid is shorter than the coracoid articulation and faces anteroventrally. Both surfaces are medially deflected. Noteworthy is the absence of a subtriangular process at the posteroventral corner of the acromial plate. The scapular blade is straight, flat medially and slightly convex laterally, with a Dshaped cross-section, especially in the proximal half. In MCNA 14461 and MCNA 14462 a dorsal prominence is present on the medial surface, close to the junction of the acromion with the scapular blade. On the medial surface, MCNA 7459 shows both a dorsal prominence close to the dorsal edge of the scapular blade and the acromion, and a ventral ridge. MCNA 7459 is the only specimen that presents both structures. Also, the dorsal prominence is more developed and sharper in MCNA 14461 than in MCNA 7459, which is more rounded and less pointed. The distal end of the scapular blade is not preserved in the Laño specimens, but it seems to have been only slightly dorsoventrally expanded in relation to the rest of the blade.

Coracoid (Figure 2.4-7). The coracoids will be described with the glenoid surface oriented pos- 

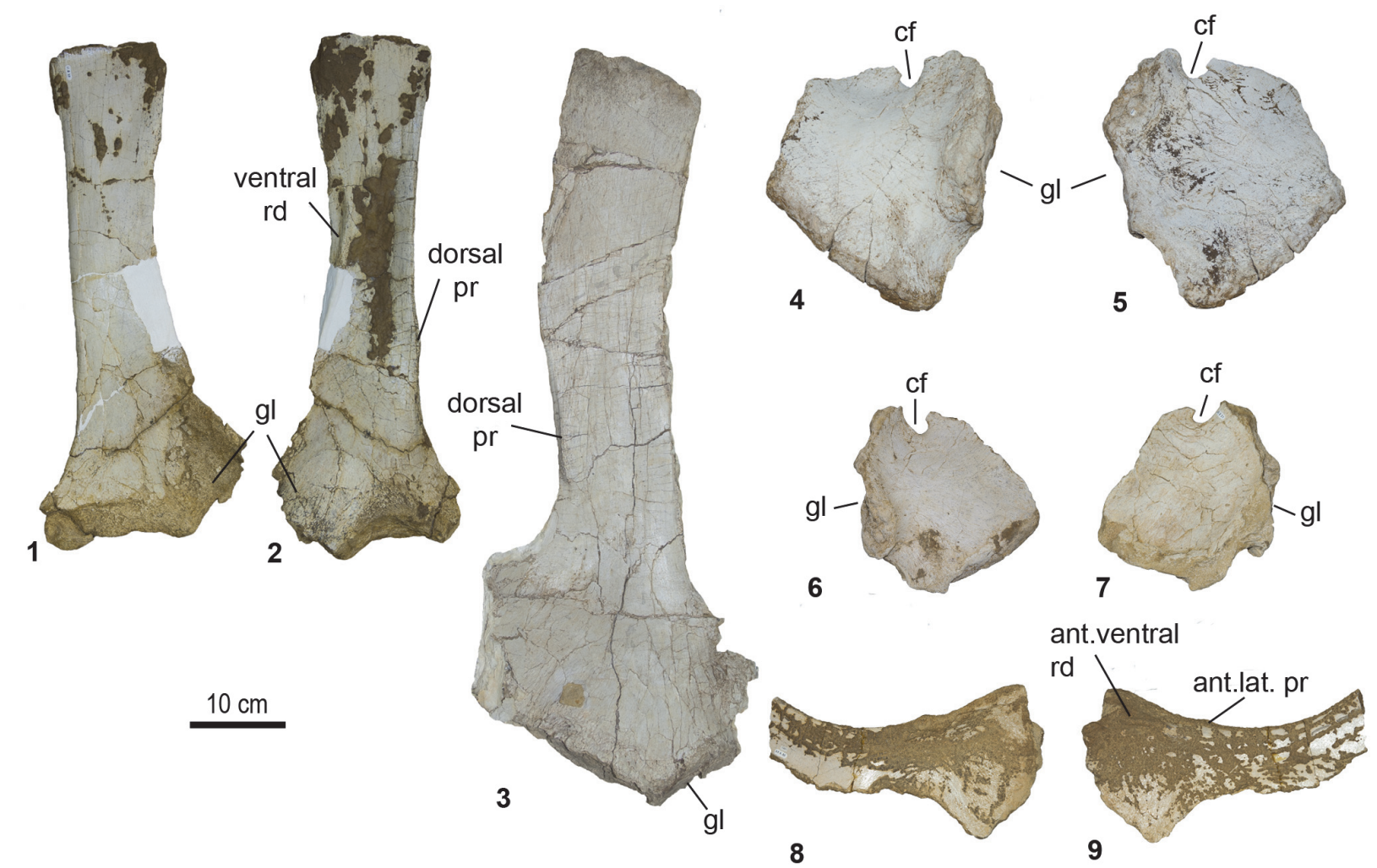

FIGURE 2. Scapular girdle bones of the titanosaurian sauropod Lirainosaurus astibiae from the Late Cretaceous of Laño (northern Spain). Left scapula (MCNA 7459) in 1. lateral and 2. medial views. Right scapula (MCNA 14461) in 3. medial view. Left coracoid (MCNA 3158) in 4. lateral and 5. medial views. Right coracoid (MCNA 7460) in 6. medial and 7. lateral views. Right sternal plate in 8. dorsal and 9. ventral views. Abbreviations: ant, anterior; cf, coracoid foramen; gl, glenoid; lat, lateral; pr, prominence, rd, ridge.

TABLE 2. Measurements of the best-preserved specimens (in $\mathrm{cm}$ ) of the pectoral girdle of the titanosaurian sauropod Lirainosaurus astibiae from the Late Cretaceous of Laño (northern Spain). Abbreviations: *: eroded edges; Max. APL: maximum anteroposterior length; Max. DVH: maximum dorsoventral height; Max./Min. DVH sb: maximum/minimum dorsoventral height of the scapular blade; Max. $L$ glenoid: maximum length of the glenoid surface.

$\begin{array}{lcccc}\text { SCAPULAE } & & & & \\ & \text { Total Length } & \text { Max. DVH sb } & \text { Min. DVH sb } & \\ \text { MCNA 7459 } & 55,19^{*} & 12.9 & 8.7 & \\ \text { MCNA 13855 } & - & 12 & 10.1 & \\ \text { MCNA 14461 } & 72.2 & 13.9 & 11.9 & \\ \text { MCNA 14462 } & - & 9.2 & - & \\ & & & & \\ \text { CORACOIDS } & & & & \\ & \text { Max. DVH } & \text { Max. APL } & \text { Foramen Width } & \text { Max. L glenoid } \\ \text { MCNA 1846 } & 25,9^{*} & 27,4^{*} & 1,6^{*} & - \\ \text { MCNA 3158 } & 24 & 23.3 & 2,2^{*} & 11.4 \\ \text { MCNA 7460 } & 17,5^{*} & 18,6^{*} & 1.7 & 10.64\end{array}$


teroventrally. The coracoid presents a subquadrangular outline. The lateral surface is convex, while the medial one is concave. The anterodorsal edge is thinner than the posteroventral one, where the surface of the glenoid is located. The coracoid foramen, which pierces the coracoid lateromedially, is situated dorsal to the glenoid articulation. It is open in MCNA 3158 and 7460 (in the former the borders are broken, but the position of the foramen and comparison with MCNA 7460 lead us to believe that it was open). The glenoid surface is larger than the scapular articulation. In lateral view, a rough surface near the anteroventral edge is present, probably for the insertion of the coracobrachialis brevis (Borsuk-Bialynicka, 1977). There is no infraglenoid lip.

Sternal Plate (Figure 2.8-9). The only sternal plate is an incomplete right specimen. It preserves its lateral and anterior borders, the lateral one being strongly concave. This element probably had a semilunar shape, as in most titanosaurs (González Riga et al., 2009). It also has an anteroventral ridge and an anterolateral prominence. The surface of the sternal plate becomes flatter towards its medial margin.

\section{Forelimb (Figure 3) (Table 3)}

Five humeri are known: two right (MCNA 7462, 7464), two left (MCNA 7463, 7465), and a poorly-preserved specimen (MCNA 14463). In addition, a right ulna is preserved (MCNA 3157).

Humerus (Figure 3.1-4). The humerus presents a long shaft, which is flattened anteroposteriorly, as in most neosauropods (Curry Rogers, 2009). The shaft is straight in anterior and posterior views. The cross-section of the diaphysis is elliptical at its narrowest point. The ends are greatly expanded lateromedially, especially the proximal one, which has a square-shaped edge. The anterior surface in its proximal half is concave. In anterior view, near the proximolateral edge, a thick, scarcely expanded and medially directed deltopectoral crest appears, which almost reaches the midheight of the diaphysis. In MCNA 7462 and 7463 a small rounded bulge can be seen just above midheight on the posterior surface, closer to the lateral than the medial margin. This feature cannot be seen in the other humeri due to the iron oxide covering. The posterodistal surface includes a concave area delimited by two ridges. The distal condyles cannot be studied in detail in any of the specimens because they are highly eroded or are not preserved. The average humeral eccentricity reaches a value of 2 .
Ulna (Figure 3.5-8). The right ulna MCNA 3157 is a slender bone with a broad proximal end, whereas the distal end is only slightly anteroposteriorly expanded. The proximal end is triradiate, slightly lateromedially compressed, with the longest process slightly posteromedially directed. The olecranon process is not prominent. The anterolateral process is shorter than the anterior one. These processes form a deep fossa for the reception of the radius. The upper medial surface is shallowly concave, and the shaft has a triangular cross-section: a prominent ridge runs from the proximal end towards the middle of the medial surface of the shaft. The posterior edge is more curved than the anterior one, which is almost straight.

\section{Pelvic Girdle (Figure 4) (Table 4)}

Four iliac remains are known: two right ones (MCNA 7466, 8609) and two left ones (MCNA $13861,14464)$. Also, a left pubis (MCNA 7467) has been recovered.

Ilium (Figure 4.1-3). The left ilium MCNA 14464 only preserves the iliac blade and the pubic peduncle. The other three specimens are fragments of the dorsal margin of the acetabulum, i.e., the junction of the iliac blade and the proximal part of the pubic peduncle (MCNA 7466, 8609, 13861). The pubic peduncle seems to have been elongate and anteroventrally oriented. In lateral view, just at the base of the pubic peduncle, a triangular hollow appears. The internal structure is highly pneumatized.

Pubis (Figure 4.4). A left pubis, broken at its midlength, is known. The proximal part is well preserved, and the distal part is eroded. The obturator foramen is large and oval. It is situated close to the dorsal end of the ischial articulation surface, which is the wider edge of the proximal plate of the pubis. The acetabulum and the iliac articulation are not well preserved. The distal blade is lateromedially compressed. The pubis of $L$. astibiae seems to have been a slender and gracile bone.

\section{Hind Limb (Figure 5) (Table 5)}

Seven femora have been recovered, including four left (MCNA 1817, 3160, 7468, 14465) and one right (MCNA 14466). In two specimens the poor state of preservation makes it difficult to know the correct orientation (MCNA 14467, 14468). Five tibiae are known: one right (MCNA 7471), three left (MCNA 2203, 13860, 14469) and the proximal part of a shaft (MCNA 14470). Three right fibulae have also been recovered (MCNA 7472, 9410, 14471). Only one left metatarsal is known (MCNA 14474). 

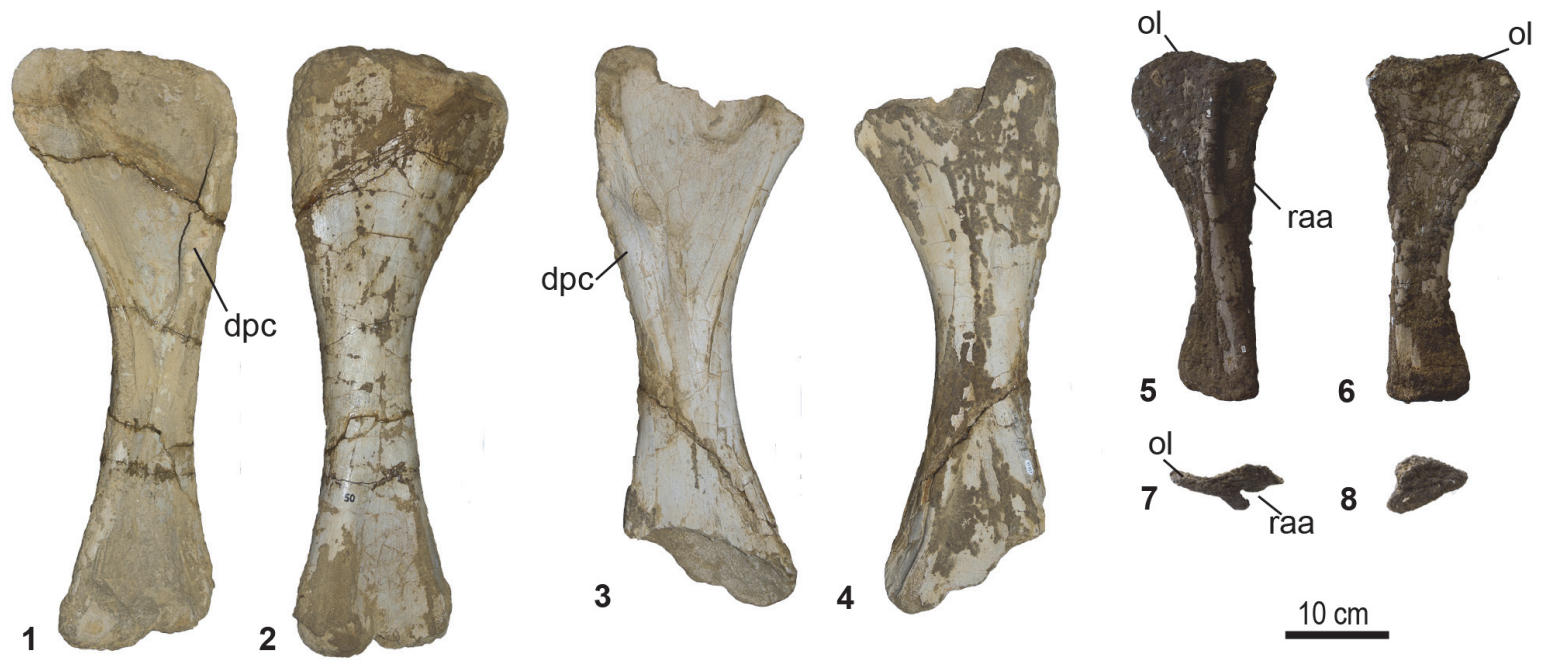

FIGURE 3. Forelimb bones of the titanosaurian sauropod Lirainosaurus astibiae from the Late Cretaceous of Laño (northern Spain). Left humerus (MCNA 7463) in 1. anterior and 2. posterior views. Right humerus (MCNA 7462 ) in 3. anterior and 4. posterior views. Right ulna (MCNA 3157) in 5. lateral, 6. medial, 7. proximal and 8. distal (lateral towards bottom) views. Abbreviations: dpc, deltopectoral crest; ol, olecranon; raa, radial articulation.

TABLE 3. Measurements of the best-preserved specimens (in $\mathrm{cm}$ ) of the forelimb of the titanosaurian sauropod Lirainosaurus astibiae from the Late Cretaceous of Laño (northern Spain). The measures with a $\approx$ symbol are approximate as iron oxides cover the surface of the bones. Abbreviations: ${ }^{* *}$ : eroded proximal and/or distal ends; Dist. Prx-D $\mathrm{dpc}$ : distance from proximal end to distal end of deltopectoral crest; Max. $\varnothing$ : maximum diameter in the narrowest part of the diaphysis; MDW: maximum width of the distal end; Min. $\varnothing$ : minimum diameter in the narrowest part of the diaphysis; MPW: maximum width of the proximal end; Per: perimeter in the narrowest part of the diaphysis; RI = average of the greatest widths of the proximal end, mid-shaft and distal end of the element/length of the element (Wilson and Upchurch, 2003).

HUMERI

$\begin{array}{lcccccccrr} & \text { Length } & \text { Max. } \varnothing & \text { Min. } \varnothing & \text { Per. } & \text { MPW } & \text { MDW } & \begin{array}{c}\text { Dist. Prx-D } \\ \text { dpc }\end{array} & \text { RI } & \text { ECC } \\ \text { MCNA 7462 } & - & 8,3 \mathrm{~cm} & 4 \mathrm{~cm} & 22,9 \mathrm{~cm} & - & - & 16.5 & - & 2.075 \\ \text { MCNA 7463 } & 53,1 \mathrm{~cm} & 8,5 \mathrm{~cm} & \approx 4,2 \mathrm{~cm} & 22,1 \mathrm{~cm} & 20,9 \mathrm{~cm} & 16,6 \mathrm{~cm} & 18.5 & - & 2.023 \\ \text { MCNA 7464 } & 66 \mathrm{~cm}^{* *} & 9,5 \mathrm{~cm} & \approx 6,5 \mathrm{~cm} & \approx 27,2 \mathrm{~cm} & 24,1 \mathrm{~cm} & 19,7 \mathrm{~cm} & 24 & 0.269 & 1.461 \\ \text { MCNA 7465 } & 55 \mathrm{~cm}^{* *} & 9,6 \mathrm{~cm} & 3,9 \mathrm{~cm} & 25 \mathrm{~cm} & 18,8 \mathrm{~cm} * * & 14 \mathrm{~cm} * * & 17 & 0.257 & 2.461\end{array}$

ULNA

$\begin{array}{cccccccc} & \text { Length } & \text { Max. } \varnothing & \text { Min. } \varnothing & \text { Per. } & \text { MPW } & \text { MDW } & \text { RI } \\ \text { MCNA } 3157 & 11,43 \mathrm{~cm} & 1,75 \mathrm{~cm} & 1,45 \mathrm{~cm} & 6,2 \mathrm{~cm} & 5,09 \mathrm{~cm} & 2,72 \mathrm{~cm} & 0.279\end{array}$

Femur (Figure 5.1-5). The shaft is straight, anteroposteriorly compressed and with an elliptical cross section. The posterior surface of the diaphysis is slightly more concave than the anterior one, and presents a flange from below the greater trochanter to the upper third of the shaft, the trochanteric shelf. The femoral head is convex, and it is directed dorsomedially. These specimens show a medial deflection that occupies the proximolateral third of the femur. The lateral bulge lies distal to the greater trochanter. The fourth trochanter is a scarcely developed ridge on the posteromedial surface of the diaphysis, just above the midshaft, which is not visible in anterior view. The distal articular surface is expanded onto the anterior and posterior surfaces of the femur, and it is beveled 

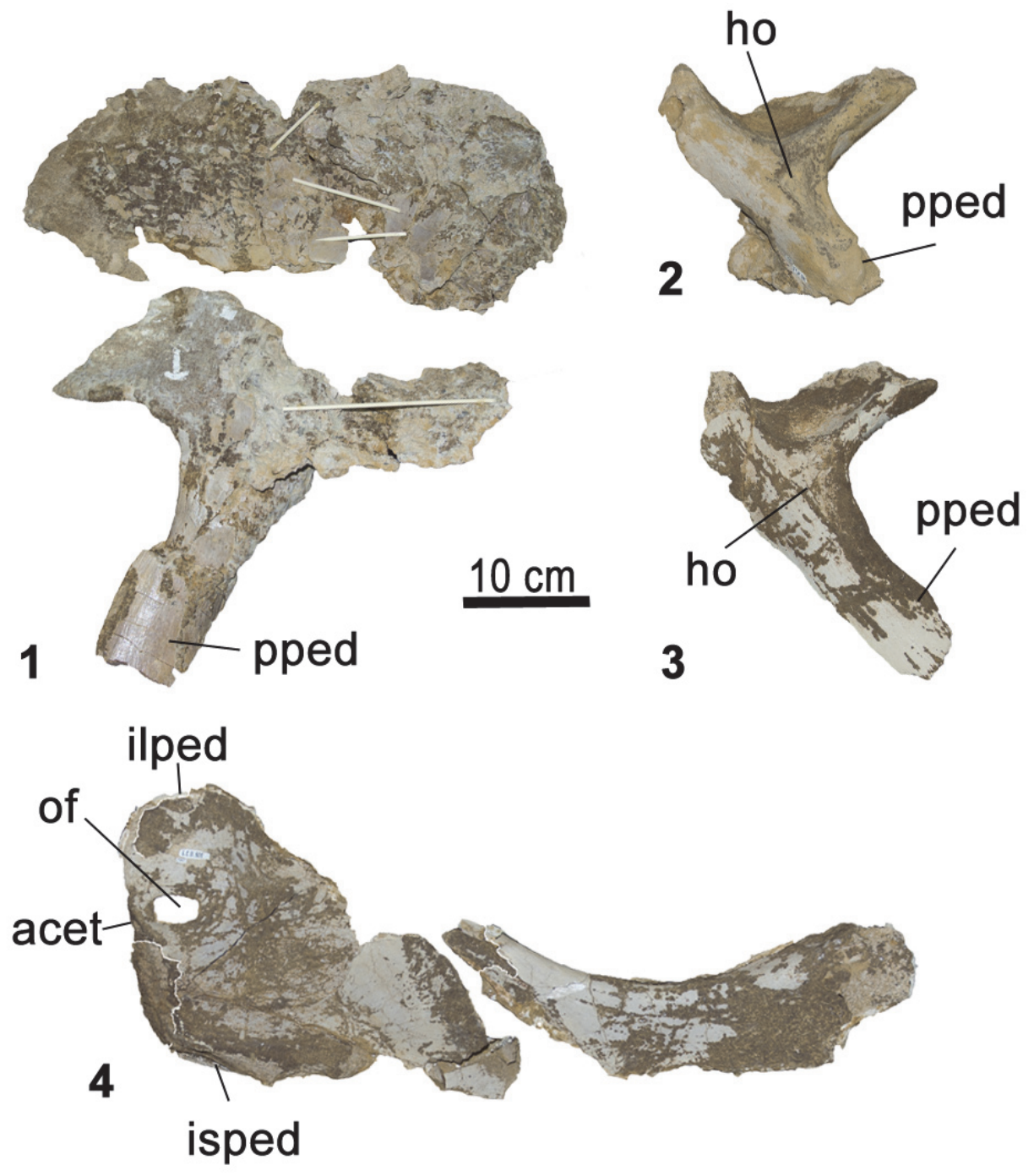

FIGURE 4. Pelvic girdle bones of the titanosaurian sauropod Lirainosaurus astibiae from the Late Cretaceous of Laño (northern Spain). Left ilium (LDL 12) in 1. lateral view. Right ilium (MCNA 7466) in 2. lateral view. Right ilium (MCNA 8609) in 3. lateral view. Left pubis in 4. medial view. Abbreviations: acet, acetabulum; ilped, iliac peduncle; isped, ischial peduncle; ho, hollow; of, obturator foramen; pped, pubic peduncle.

TABLE 4. Measurements of the best-preserved specimens (in $\mathrm{cm}$ ) of the pelvic girdle of the titanosaurian sauropod Lirainosaurus astibiae from the Late Cretaceous of Laño (northern Spain). Abbreviations: *: eroded edges; APL ac: anteroposterior length of the acetabular surface; Max. APL prxb: maximum anteroposterior length of the proximal blade; Max./Min. L foramen: maximum/minimum length of the foramen; Min. APLdb: minimum anteroposterior length of the distal blade.

PUBIS

\section{Total Length Max. APL prxb Min. APL db}

MCNA 7467
$53,5^{*}$

18.5
6.1
APL ac

8.5

\section{Max. $L$ foramen Min. $L$ foramen}



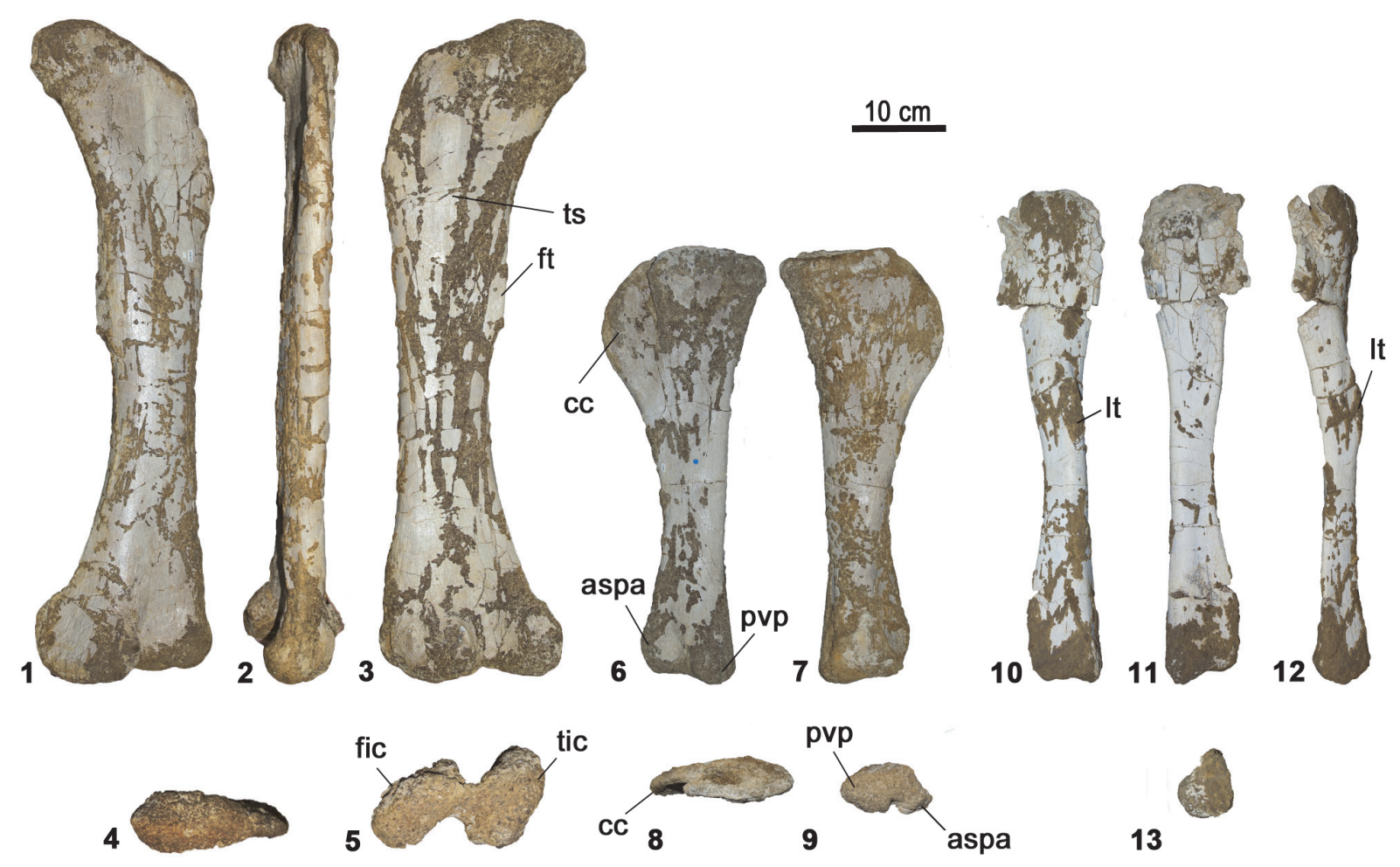

FIGURE 5. Hindlimb bones of the titanosaurian sauropod Lirainosaurus astibiae from the Late Cretaceous of Laño (northern Spain). Left femur (MCNA 7468) in 1. anterior, 2. lateral, 3. posterior, 4. proximal (posterior towards top) and 5. distal (posterior towards top) views. Left tibia (MCNA 13860) in 6. lateral, 7. medial, 8. proximal (medial towards top) and 9. distal (medial towards top) views. Right fibula (MCNA 9410) in 10. lateral, 11. medial, 12. posterior and 13. distal (posterior towards top) views. Abbreviations: aspa, articular surface for the ascending process; cc, cnemial crest; fic, fibular condyle; ft, fourth trochanter; It, lateral trochanter; tic, tibial condyle; pvp, posteroventral process; ts, trochanteric shelf.

relative to the long axis of the shaft, especially in the posterior surface. The fibular condyle - which is unequally divided into a small posterodorsal portion and a larger ventral surface - is anteroposteriorly more compressed than the tibial condyle, and they are separated by an intercondylar groove. Both distal condyles are dorsomedially directed. The average femoral eccentricity is higher than 2.

Tibia (Figure 5.6-9). The tibiae are slender, have a mediolaterally compressed diaphysis, and the proximal articular surface is anteroposteriorly compressed and oval. The cnemial crest is an expanded flat rounded ridge. With the flat subtriangular surface of the distal end treated as the anterior surface, the cnemial crest projects anterolaterally. This cnemial crest delimits a shallow surface for the reception of the proximal end of the fibula. In MCNA 2203, a prominent anteromedial ridge close to the distal end delimits two concave surfaces, one anteriorly located and the other medially directed. In the other specimens these surfaces and the ridge are not as conspicuous as in MCNA 2203. The distal end of the tibia is more or less subquadrangular in MCNA 2203 and 7471, but longer anteroposteriorly in MCNA 13860. The distal posteroventral process is short. The articular surfaces for the ascending process of the astragalus and for the posteroventral process of the tibiae of $L$. astibiae are not well pronounced.

Fibula (Figure 5.10-13). The fibula is more slender than the tibia. The cross section of the diaphysis at its medial point is more or less subcircular. The extremities are more expanded than the diaphysis, especially the proximal one. The proximal end is lateromedially compressed, the lateral surface being convex and the medial one concave. Although the preservation of the proximal end of most of the fibulae is not perfectly preserved, in some specimens - e.g., MCNA 14471 - the absence of an anteromedial crest, like the one present in the fibula of the basal somphospondylan sauropod Tastavinsaurus sanzi (Canudo et al., 
TABLE 5. Measurements of the best-preserved specimens (in $\mathrm{cm}$ ) of the hindlimb of the titanosaurian sauropod Lirainosaurus astibiae from the Late Cretaceous of Laño (northern Spain). The measures with a $\approx$ symbol are approximate as iron oxides cover the surface of the bones. Abbreviations: ${ }^{* *}$ : eroded proximal and/or distal ends; ECC = femoral mid-shaft width/femoral anteroposterior width (Wilson and Carrano, 1999); Max. $\varnothing$ : maximum diameter in the narrowest part of the diaphysis; Max. MLW D/Prx: maximum mediolateral width of the distal/proximal end; MDW: maximum width of the distal end; Min. $\varnothing$ : minimum diameter in the narrowest part of the diaphysis; MLW: mediolateral width; MPW: maximum width of the proximal end; Per: perimeter in the narrowest part of the diaphysis; RI = average of the greatest widths of the proximal end, mid-shaft and distal end of the element/length of the element (Wilson and Upchurch, 2003).

FEMORA

$\begin{array}{lccccccrr} & \text { Length } & \text { Max. } \varnothing & \text { Min. } \varnothing & \text { Per. } & \text { MPW } & \text { MDW } & \text { RI } & \text { ECC } \\ \text { MCNA 1817 } & - & 9,2 \mathrm{~cm} & 4,8 \mathrm{~cm} & 24,8 \mathrm{~cm} & - & - & - & 1.916 \\ \text { MCNA 3160 } & 71,1 \mathrm{~cm}^{* *} & 11,1 \mathrm{~cm} & 4,3 \mathrm{~cm} & 27,7 \mathrm{~cm} & - & 17,5 \mathrm{~cm} & - & 2.581 \\ \text { MCNA 7468 } & 68,2 \mathrm{~cm} & 9,1 \mathrm{~cm} & 5,4 \mathrm{~cm} & 25,2 \mathrm{~cm} & 18,3 \mathrm{~cm} & 17,6 \mathrm{~cm} & 0.219 & 1.685 \\ \text { MCNA 14465 } & 68 \mathrm{~cm} & 9,2 \mathrm{~cm} & 4,3 \mathrm{~cm} & 24,1 \mathrm{~cm} & 15,9 \mathrm{~cm} & 17,7 \mathrm{~cm} & 0.209 & 2.139 \\ \text { MCNA 14466 } & 81,6 \mathrm{~cm} & 12,1 \mathrm{~cm} & 5,3 \mathrm{~cm} & 33 \mathrm{~cm} & 22,5 \mathrm{~cm} & - & - & 2.283 \\ \text { MCNA 14468 } & 75 \mathrm{~cm}^{* *} & 13,8 \mathrm{~cm} & 5,2 \mathrm{~cm} & 35,2 \mathrm{~cm} & 23,6 \mathrm{~cm}^{* *} & - & - & 2.654\end{array}$

TIBIAE

$\begin{array}{lccccccc} & \text { Length } & \text { Max. } \varnothing & \text { Min. } \varnothing & \text { Per. } & \text { MPW } & \text { MDW } & \text { RI } \\ \text { MCNA 2203 } & - & 7,7 \mathrm{~cm} & 4,1 \mathrm{~cm} & 21,4 \mathrm{~cm} & - & 10,2 \mathrm{~cm} & - \\ \text { MCNA } 13860 & 41,2 \mathrm{~cm} & 5,7 \mathrm{~cm} & 3,3 \mathrm{~cm} & 17,6 \mathrm{~cm} & 13,9 \mathrm{~cm} & 9,7 \mathrm{~cm} & 0.237\end{array}$

FIBULAE

$\begin{array}{lccccccc} & \text { Length } & \text { Max. } \varnothing & \text { Min. } \varnothing & \text { Per. } & \text { MPW } & \text { MDW } & \text { RI } \\ \text { MCNA 7472 } & 55 \mathrm{~cm}^{* *} & \approx 5 \mathrm{~cm} & \approx 3,5 \mathrm{~cm} & \approx 15 \mathrm{~cm} & 10,2 \mathrm{~cm} & 7,3 \mathrm{~cm} & 0.136 \\ \text { MCNA } 9410 & 51,4 \mathrm{~cm}^{* *} & 4,6 \mathrm{~cm} & 3,8 \mathrm{~cm} & 14,1 \mathrm{~cm} & - & \approx 7,3 \mathrm{~cm} & - \\ \text { MCNA } 14469 & 47,5 \mathrm{~cm}^{* *} & 6,6 \mathrm{~cm} & 3,6 \mathrm{~cm} & - & - & - & - \\ \text { MCNA } 14471 & 42,3 \mathrm{~cm} & 4,4 \mathrm{~cm} & 2,8 \mathrm{~cm} & 13,5 \mathrm{~cm} & 10,3 \mathrm{~cm} & 6,5 \mathrm{~cm} & 0.167\end{array}$

METATARSAL

2008, fig. 15.E), can be confirmed. In lateral view, the shaft of the fibula is slightly sigmoidal to concave in its anterior surface. The oval lateral trochanter appears in the middle part of the lateral surface of the diaphysis. The distal end has a triangular profile. In medial view, a concavity can be seen; this is the articulation of the fibula with the astragalus.

Metatarsal (Figure 6). The left metatarsal III (MCNA 14474) is slender; the proximal end is expanded and has a rectangular profile. The distal

\section{$\underset{\text { Prx }}{\operatorname{Max.~MLW~Max.~MLW~D~}}$}

1.8

1.9 end is less expanded and has two condyles, the medial being larger than the lateral one. Proximally, the medial and lateral surfaces have welldefined triangular areas of articulation for metatarsals II and IV.

\section{Dermal Armour (Figure 7)}

Two incomplete osteoderms (MCNA 14473, 14474 ) have been recovered. They seem to have a flat base and two lateral surfaces that join dorsally, perhaps producing a triangular profile, one of them 

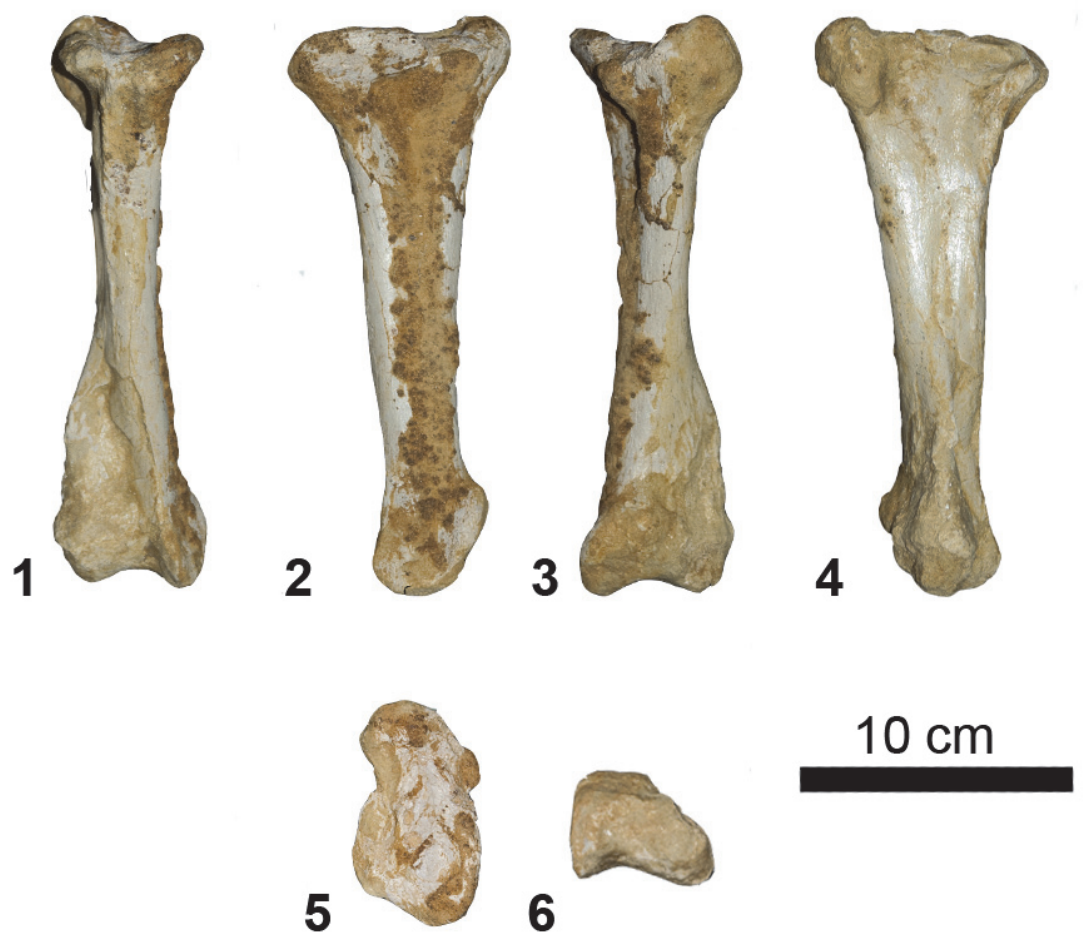

FIGURE 6. Left metatarsal III (MCNA 14474) of the titanosaurian sauropod Lirainosaurus astibiae from the Late Cretaceous of Laño (northern Spain) in 1. plantar, 2. lateral, 3. dorsal, 4. medial, 5. proximal and 6. distal views (dorsal towards top).

being more perpendicular to the ventral surface than the other. Although most of the osteoderm bodies are missing, they could have belonged to the ellipsoid morphotype described by D'Emic et al. (2009), being part of the "root" first described in the osteoderms of Ampelosaurus atacis (Le Loeuff et al., 1994; Le Loeuff, 1995, 2005).

\section{COMPARISONS}

\section{Pectoral Girdle}

Elements from the scapular girdle are known for several European titanosaurs: Lirainosaurus astibiae, Ampelosaurus atacis, Atsinganosaurus velauciensis and Magyarosaurus dacus (but the preservation of the remains of the latter taxon complicates its comparison with the other taxa). As observed in the material from the type locality of Laño, the scapula of $L$. cf. astibiae is laterally convex and has a ventral ridge and a dorsal prominence on the medial surface. $A$. atacis also has a ventral crest on its medial surface, but not the dorsal one (it shows a medio-dorsal protuberance).
However, the ventral crest of Ampelosaurus is not as prominent as the one present in the scapula of Lirainosaurus. Opisthocoelicaudia presents a ventral rugosity in the medial surface of the scapular blade for the insertion of the serratus superficialis muscle (Borsuk-Bialynicka, 1977). The ventral ridges shown by the scapulae of Lirainosaurus and Ampelosaurus probably have the same function as that of Opisthocoelicaudia skarzynskii, although in these European titanosaurs they are much more developed. In Atsinganosaurus and Magyarosaurus (NHMUK R. 3816) there are no medial ridges. Saltasaurus loricatus and Neuquensaurus australis do present a dorsal prominence in the medial surface of the scapular blade similar to that of Lirainosaurus - though more developed, they are more like a ridge - but these Argentinean titanosaurs do not show a medial ventral ridge (Powell, 1992). Therefore, the combination of a dorsal prominence and a ventral ridge on the medial surface of the scapular blade is only known in the scapulae of Lirainosaurus. 

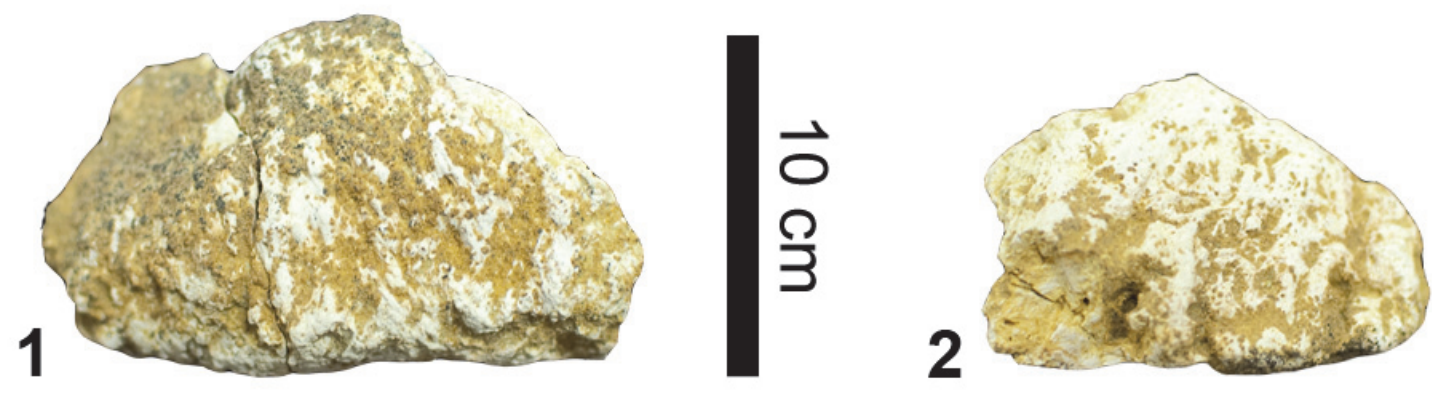

FIGURE 7. Osteoderms (MCNA 14473 and 14474) of the titanosaurian sauropod Lirainosaurus astibiae from the Late Cretaceous of Laño (northern Spain).

The coracoid has a subquadrangular profile in all the European titanosaurs, but this is a condition usually found in Titanosauria, except in some basal forms such as the African titanosaur Malawisaurus (Gomani, 2005). Also, all of the European titanosaurs present the coracoid foramen close to the suture of the scapula with the coracoid, but only in $L$. astibiae and most of the specimens of $A$. atacis does this foramen open dorsally. Le Loeuff (2005) described some coracoids of $A$. atacis, which have this foramen closed dorsally by a thin wall of bone that can be easily damaged. The dorsal surface of the coracoid foramen is broken in MCNA 3158, so it could have been closed as in A. atacis. In Rapetosaurus krausei the coracoid foramen is open in a juvenile specimen (Curry Rogers, 2009), a condition that could have also applied to the specimens of $L$. astibiae. Other titanosaurs also present the coracoid foramen close to the articulation with the scapula, such as the Argentinean Rinconsaurus caudamirus (Calvo and González Riga, 2003; V.D.D. personal observation). The coracoids of $L$. astibiae do not present an infraglenoid lip, as seen in some saltasaurids such as Saltasaurus loricatus (Powell, 1992, V.D.D. personal observation) or Opisthocoelicaudia skarzynskii (Borsuk-Bialynicka, 1977).

The lateral surface of the sternal plate of Lirainosaurus astibiae is strongly concave (as observed in the Laño and Chera specimens), as in all titanosaurs (e.g., Rapetosaurus krausei). Also, the surface of the sternal plates of these titanosaurs becomes flatter towards its medial edge. Maxakalisaurus topai (Kellner et al., 2006) presents an anteroventral ridge in the sternal plate, and the same elements of Neuquensaurus australis
(Huene, 1929) show an anterolateral ridge. However, the combination of this ridge with the anterolateral process and the concave lateral edge of the sternal plate has only been seen in Lirainosaurus (Sanz et al., 1999; Company et al., 2009).

\section{Forelimb}

Forelimb bones are known from all the titanosaurs of the Ibero-Armorican Island and Magyarosaurus. Lirainosaurus, Atsinganosaurus and Magyarosaurus present slender humeri, with greatly expanded ends, especially the proximal one. The humeri of Ampelosaurus are more robust and have the proximal end greatly expanded, with similar proportions to the humeri of saltasaurids, the breadth of the proximal end being more than $50 \%$ of the humeral length. The dorsal edge of the proximal end is flat in all of these titanosaurs, as is typical in most titanosaurs except Saltasaurus loricatus (Powell, 1992; V.D.D. personal observation), where it is sigmoidal. Also, the main axis of the diaphyses of all the European titanosaurs are straight with an elliptical cross-section, and the deltopectoral crest is thick and medially directed in all of them. NHMUK R. 3849 presents a diaphysis that is narrower at mid-shaft than that in other European titanosaurs. The medial margin of the humeri of all the European titanosaurs is concave, especially at the mid-shaft. Nevertheless, the lateral margin is straight in the French taxa, while Lirainosaurus and Magyarosaurus have slightly concave lateral margins. The ulnae of $A$. atacis are more robust than those of $L$. astibiae, $L$. cf. astibiae and $M$. dacus (NHMUK R. 3849), and the lateral ridge is more prominent and the medial upper surface is flatter in the French specimens (MDE C3- 
$1296,1490)$. L. astibiae has a more lateromedially compressed proximal end, and the fossa between the anterior and anterolateral process is deeper and narrower than that in the other European titanosaurs. The olecranon process is more prominent in L. cf. astibiae than in L. astibiae (Company et al., 2009).

\section{Pelvic girdle}

Besides Lirainosaurus, only Ampelosaurus and Paludititan preserve pelvic elements. The ilia of $L$. astibiae are anteroposteriorly more concave above the acetabulum than in the specimen of $P$. nalatzensis; the pubic peduncles are robust and anteroventrally oriented in both taxa. Only $L$. astibiae presents a triangular hollow at the base of the pubic peduncle of the ilium, as in the Argentinean saltasaurine Rocasaurus muniozi (Salgado and Azpilicueta, 2000; V.D.D., personal observation), but it is also present as a presumable convergence in the basal eusauropod Cetiosaurus (Upchurch and Martin, 2003 fig. 11A, B).

Damage to the pubis of $L$. astibiae makes comparison with $A$. atacis and $P$. nalatzensis difficult. However, the obturator foramen seems to be larger and more dorsally located in the pubis of $L$. astibiae.

\section{Hindlimb}

Hindlimb bones are known for all the European titanosaurian taxa. All of them except $A$. velauciensis preserve femora, which are anteroposteriorly compressed and have a straight diaphysis. They also show a lateral bulge and, just above it, the proximolateral margin is medial to the lateral margin of the distal half of the shaft - as in most Titanosauriformes (Wilson, 2002; Upchurch et al., 2004; Mannion et al., 2013) - but in the Romanian titanosaurs this feature cannot be observed due to the preservation of the specimen (NHMUK R. 3849). The femora of $L$. astibiae and $L$. cf. astibiae are more slender than those of $A$. atacis. The femoral head is dorsomedially directed, and the fourth trochanter is reduced and posteromedially placed in the diaphysis in all of them. In the upper third of the posterior surface of the femoral shaft of $L$. astibiae, the greater trochanter extends distally like a flange. This flange, or trochanteric shelf, is also present in the titanosaurs Saltasaurus loricatus, Neuquensaurus australis, Rocasaurus muniozi, Rapetosaurus krausei and Jainosaurus cf. septentrionalis, but also in more basal somphospondylans too (Curry Rogers, 2009; Wilson et al., 2011; Mannion et al., 2013; V.D.D., personal observation).
The distal condyles are more medially directed in the Spanish specimens than in A. atacis. Vila et al. (2012) studied several femora assigned to titanosaurs from upper Campanian to uppermost Maastrichtian fossil-sites of Spain and Southern France, referring them to different types according to a set of anatomical features. One of the types comprises two specimens from Fox-Amphoux and probably three more femora from Bellevue (Campagne-surAude). This material has been referred to cf. Lirainosaurus astibiae, because of its ECC of about 2 (200\%), the scarcely developed, ridgeshaped fourth trochanter, and the anteroposteriorly compressed distal end with medially directed distal condyles. However, these French femora do not share with Lirainosaurus astibiae the following features: Lirainosaurus presents an RI of about 0.2, whereas the French femora exhibit an RI of almost 0.16 ; in the French femora the lateral bulge is anteriorly projected in anterior and lateral views, whereas in Lirainosaurus it is straight; Lirainosaurus presents a trochanteric shelf in posterior view; and the intercondylar sulcus is much more developed in Lirainosaurus than in the French specimens. Also, Vila et al. (2012) noted that the femora assigned to cf. Lirainosaurus astibiae are morphologically similar to those they had assigned to Ampelosaurus atacis, differentiating them only in the proximodistal development of the lateral bulge and the position of its distalmost edge. This highlights the need for particular care in attributing isolated femora of this type to Lirainosaurus.

All the Ibero-Armorican taxa are represented by tibiae $-M$. dacus preserves a distal fragment of a tibial diaphysis (NHMUK R. 3850) - and these are very similar. The tibiae of Ampelosaurus and Atsinganosaurus seem to be more robust than those of Lirainosaurus (except for the right tibia MDE C3-1303 of $A$. atacis, which is more gracile). A. velauciensis and NHMUK R. 3850 also have a prominent anteromedial ridge close to the distal extremity of the tibia delimiting two concave surfaces. All of them show a distal end whose transverse diameter is longer than the anteroposterior one except Lirainosaurus astibiae, whose distal end is more subquadrangular. This feature is probably a diagnostic character of the Iberian taxon.

Only $L$. astibiae and $A$. atacis preserve complete fibulae $(M$. dacus preserves some fragments of the diaphysis). The main difference between the two taxa is that the proximal and distal extremities of the tibiae of $A$. atacis are more expanded than those of $L$. astibiae. Also, L. astibiae does not present a sigmoidal ridge associated with the lateral 
trochanter, as present in the fibulae of $A$. atacis (Le Loeuff, 1992).

\section{Dermal Armour}

The presence of osteoderms is a diagnostic feature of lithostrotian titanosaurs (Upchurch et al., 2004). Osteoderms are known in Lirainosaurus and Ampelosaurus, but the poor preservation of those referred to Lirainosaurus makes detailed comparison between these two taxa difficult: $A$. atacis has the diagnostic large spines (Le Loeuff et al., 1994) which are included in the ellipsoid morphotype of D'Emic et al. (2009), a morphotype that the osteoderms of Lirainosaurus might also have displayed. Recently, several osteoderms have been described from the "Lo Hueco" site (Cuenca, Spain) (Ortega et al., 2012), and these also differ from those of $L$. astibiae. They are elongated with a concave base and a convex external surface, and their morphology varies between the "spines" described by Le Loeuff et al. (1994) and the "bulb and root" ellipsoid morphotype proposed by D'Emic et al. (2009). The bulb-shaped end is formed by a circular surface and is delimited by a cingulum. They also present a shallow sagittal crest. The available evidence shows that Lirainosaurus did not possess dermal armour like that of Ampelosaurus. Lirainosaurus astibiae is represented by abundant remains in Laño, but only two fragmentary osteoderms have been found. This suggests that its dermal armour could have been lighter than that present in other lithostrotians, such as Ampelosaurus or the titanosaurs from Lo Hueco.

\section{DISCUSSION}

Lirainosaurus astibiae shares one synapomorphy with Titanosauriformes: the proximal third of the femoral shaft, just above the lateral buldge, is deflected medially (Salgado et al., 1997; Wilson and Sereno, 1998; Wilson, 2002; Mannion et al., 2013). Mannion and Calvo (2011) suggest that the presence of an oval (rather than subcircular) obturator foramen in the pubis (like the one that Lirainosaurus astibiae presents), with the long axis oriented in the same plane as the long axis of the pubic shaft, might be a titanosauriform characteristic. Like somphospondylans, $L$. astibiae has a scapular glenoid surface that is strongly bevelled medially, and the proximal end of the humerus is flat in anterior view (Wilson and Sereno, 1998; Wilson, 2002). Moreover, the femoral fourth trochanter is reduced to a subtle buldge (D'Emic, 2012). Titanosaurs have femoral eccentricity greater than 1.85 (Wilson and Carrano, 1999), and the femora of $L$. astibiae easily reach a value of 2 . In addition, the sternal plate has a strongly concave lateral edge, as in all other titanosaurs (Curry Rogers, 2009). It also shares with Lithostrotia the presence of osteoderms (Upchurch et al., 2004; D'Emic, 2012), and the anterior crest of the humerus extends medially across its anterior face (Mannion et al., 2013). Lirainosaurus shares with Saltasauridae the rectangular profile of the coracoid, the distal expansion of the humeral deltopectoral crest, the femoral midshaft lateromedial diameter that is more than $185 \%$ the anteroposterior diameter, the distal condyles of the femur bevelled dorsomedially (Wilson, 2002), and the presence of a posterolateral bulge around the level of the deltopectoral crest of the humerus (D'Emic, 2012). However, the coracoid does not have an infraglenoid lip, which is a feature shown by several saltasaurids, such as Opisthocoelicaudia and Saltasaurus (Wilson, 2002).

The trochanteric shelf seems to be a diagnostic feature of the femora of derived lithostrotians D'Emic (2012) established it as a synapomorphy of the group Alamosaurus + "Saltasaurini" -, as it is present in Saltasaurus loricatus, Neuquensaurus australis, Rocasaurus muniozi, Rapetosaurus krausei, Jainosaurus cf. septentrionalis, and also in Lirainosaurus astibiae. In addition, a subtriangular process at the posteroventral corner of the acromial plate of the scapula is generally absent in more derived titanosaurs, although it is present in some of them, e.g., Alamosaurus (D'Emic et al., 2011) and Elaltitan (Mannion and Otero, 2012).

One interesting character observed in Lirainosaurus is the presence of a deep triangular hollow on the lateral surface of the ilia, just at the base of the pubic peduncle. This hollow is also present in the ilia of the saltasaurine titanosaur Rocasaurus muniozi (Salgado and Azpilicueta, 2000; V.D.D., personal observation), but it has not been known in other titanosaurs until now.

The rough anteroventral surface of the coracoid, visible in lateral view, seems to be a genuine feature shared by Lirainosaurus astibiae and Opisthocoelicaudia skarzynskii. This character is an unusual feature among Sauropoda, and, although it is not described in Alamosaurus, it could be a synapomorphy of the opisthocoelicaudine titanosaurs.

As previously hypothesized by Sanz et al. (1999) and Díez Díaz et al. (2011, 2012, 2013), and after the study of the appendicular material in this paper, Lirainosaurus astibiae is considered to be a derived member of Lithostrotia, which also 
shares several synapomorphies with Saltasauridae. However, Lirainosaurus is not a saltasaurid as it lacks some of the most diagnostic features of this clade, such as the presence of an infraglenoid lip in the coracoid, a rounded process at the junction of the proximal and lateral surfaces of the humerus, and humeral distal condyles that are divided (Wilson, 2002; Upchurch et al., 2004).

Sanz et al. (1999) considered there to be two appendicular autapomorphies of Lirainosaurus astibiae, both related to the scapular girdle: the presence of a ridge in the ventral margin on the medial side of the scapular blade, and an anterolateral process on the sternal plate. Upchurch et al. (2004) expressed their doubts about the validity of these autapomorphies, as they also appear in other titanosaurs, e.g., Opisthocoelicaudia (Borsuk-Bialynicka, 1977). As said above, the ventral ridge on the medial surface of the scapular blade also appears in Ampelosaurus, but is not as prominent as that of Lirainosaurus, and Opisthocoelicaudia presents a rugose ventral surface. The dorsal prominence is present in Saltasaurus loricatus and Neuquensaurus autralis as well (Powell, 1992), but the combination of a dorsal prominence and a ventral ridge on the medial surface of the scapular blade is only known in the scapulae of $L$. astibiae (including the material from Laño and the referred remains from Valencia), although some specimens from Laño do not show this ventral ridge. This variation could be due to ontogenetic changes or sexual dimorphism. Nevertheless, the small sample of scapular remains referred to Lirainosaurus from the fossil-sites of Laño and Chera makes it difficult to confirm this hypothesis. As there is no current evidence to support either ontogenetic changes or sexual dimorphism, this difference is regarded as being due to individual variation. Some titanosaurs, such as Maxakalisaurus topai (Kellner et al., 2006), present an anteroventral ridge in the sternal plate, so this cannot be considered a diagnostic feature of $L$. astibiae. Nevertheless, the presence of this ridge together with the anterolateral process and the strongly concave lateral edge of the sternal plate is considered to be diagnostic of Lirainosaurus astibiae. Also, the subquadrangular profile of the distal end of the tibia of Lirainosaurus astibiae could be regarded as an autapomorphy within Titanosauria, as the other titanosauriforms show tibial distal ends that are more expanded transversely than anteroposteriorly. However, Mannion and Otero (2012) also observed a subcircular distal end for the fibula of Antarctosaurus wichmannianus, and noted it as a possible autapomorphy of this taxon.

\section{Estimation of Body Size and Mass for Lirainosaurus astibiae}

We have followed the equations proposed by Seebacher (2001), Packard et al. (2009) and Campione and Evans (2012) in estimating the body size and mass of Lirainosaurus astibiae. With the smallest humerus and femur recovered from Laño we obtain a size of 3.86 meters and a mass of 1.54 tonnes (Packard et al., 2009) and 1.74 tonnes (Campione and Evans, 2012), whereas with the largest of these elements the results are 5.98 meters and 2.92 tonnes (Packard et al., 2009) and 3.98 tonnes (Campione and Evans, 2012). However, these results should be taken cautiously, as pneumaticity means that sauropods may increase their size by reducing their weight (Gascó, 2009).

Taking these results into account, we tentatively propose a body length of 4 meters, or as much as 6 meters for the largest individuals, and a body mass of ca. 2-4 tonnes for adult individuals of Lirainosaurus astibiae. The measures and the RI of the appendicular skeleton, in conjunction with the body size and mass, confirm that this Iberian taxon was a small-sized, slender titanosaur, as previously suggested by Company (2011) on the basis of histological analyses of fore and hindlimb bones referred to Lirainosaurus cf. astibiae from Chera (Spain).

\section{CONCLUSIONS}

The description of the appendicular skeleton and dermal armour of Lirainosaurus astibiae increases what is known about this Iberian sauropod, which is now one of the best-known titanosaurs. Our study supports the idea that Lirainosaurus is clearly different from other European titanosaurs (see previous works by Sanz et al., 1999; Díez Díaz et al., 2011, 2012, 2013). These differences are centred mainly on the structures observed in the scapula and sternal plate, the triangular hollow at the base of the pubic peduncle, and the slenderness of the forelimb and hindlimb bones. The presence in L. astibiae of a dorsal prominence and a ventral ridge in the medial surface of the scapular blade, the combination of an anterolateral process and an anteroventral ridge in the sternal plate, and the subquadrangular profile of the distal end of the tibia are considered to be diagnostic features. Lirainosaurus is a derived lithostrotian that could be closely related to Salta- 
sauridae according to the appendicular characters that it shares with this group of derived titanosaurs.

Equations for predicting body mass and size in sauropods suggest a body size of 4-6 meters and a body mass of at least 2-4 tonnes for the largest individuals of Lirainosaurus astibiae, it being one of the most slender titanosaurs known to date.

\section{ACKNOWLEDGEMENTS}

We would like to thank J. Carmelo Corral and J. Alonso (Museo de Ciencias Naturales de Alava/ Arabako Natur Zientzien Museoa, Vitoria-Gasteiz, Spain), B. Madarieta (Museo Vasco de Historia de la Medicina y de las Ciencias of Leioa, Spain), J. Company (Universidad Politécnica de Valencia, Spain), R. Allain and N. Bardet (Muséum National d'Histoire Naturelle de Paris, France), J. Le Loeuff (Musée des Dinosaures of Espéraza, France), G. Garcia and X. Valentin (IPHEP, Université de Poitiers, France), P. Barrett (British Natural History Museum, London, U.K.), R. Barbieri and C. Muñoz (Museo Provincial Carlos Ameghino, Cipolleti, Argentina), I. Cerda (Museo Regional de Cinco Saltos, Argentina), J. E. Powell (Universidad Nacional de Tucumán, Argentina), and M. Reguero (Museo de La Plata, Argentina) for allowing access to the material in their care. We would also like to thank X. Murelaga (Universidad del País Vasco/ EHU, Bilbao, Spain) and P. Dieudonné (Université Montpellier 2, France) for helping in the restoration of some of the specimens, and P. Mannion (Imperial College of London, U.K.), T. Tortosa (Muséum d'Histoire Naturelle, Aix-en-Provence, France), $\mathrm{H}$. Mallison (Museum für Naturkunde, Berlin, Germany), I.D. Martínez (Universidad de la Rioja, Spain) and F. Gascó (Dinópolis, Spain) for their useful comments on the postcranial anatomy of the sauropods. P.D. Mannion (Imperial College of London, U.K.) and an anonymous reviewer provided useful comments that greatly improved this manuscript. Special thanks are owed to R. Glasgow for checking the English of the manuscript. This research was supported by a predoctoral grant BES-2008-006370 associated with the project CGL2007-64061/BTE of the Ministerio de Ciencia e Innovación (currently Ministerio de Economía y Competitividad, MINECO), Spain. Financial support was also provided by the research project CGL2010-18851/BTE of the MINECO, and by the research groups IT-320-10 and IT-834-13 of the Gobierno Vasco/EJ.

\section{REFERENCES}

Astibia, H., Corral, J.C., Murelaga, X., Orue-Etxebarria, X., and Pereda-Suberbiola, X. 1999. Geology and palaeontology of the Upper Cretaceous vertebratebearing beds of the Laño quarry (Basque-Cantabrian Region, Iberian Peninsula). Estudios del Museo de Ciencias Naturales de Álava 14 (Número Especial 1), 1-380.

Astibia, H., García-Garmilla, F., Orue-Etxebarría, X., Rodríguez-Lázaro, J., Buscalioni, A.D., and Sanz, J.L. 1987. The Cretaceous-Tertiary boundary in a sector of the south limb o the Miranda-Treviño synclinal: the first appearance of Chelonia and Archosauria in the Basque Country. Cretaceous Research 8, 15-27.

Astibia, H., Buffetaut, E., Buscalioni, A.D., Cappetta, H., Corral, C., Estes, R., García-Garmilla, F., Jaeger, J.J., Jiménez-Fuentes, J., Le Loeuff, J., Mazin, J.M., Orue-Etxebarria, X., Pereda-Suberbiola, X., Powell, J.E., Rage, J.-C., Rodríguez-Lázaro, J., Sanz, J.L., and Tong, $H$. 1990. The fossil vertebrates from Laño (Basque Country, Spain); new evidence on the composition and affinities of the Late Cretaceous continental faunas of Europe. Terra Nova 2, 460-466.

Baceta, J.I., Pujalte, V., and Orue-Etxebarria, X. 1999. The vertebrate fossil-bearing sites of the Laño quarry (Basque-Cantabrian Region): stratigraphical and palaeogeographical context. Estudios del Museo de Ciencias Naturales de Álava, 14 (Número Especial 1), 13-28.

Berreteaga, A. 2008. Estudio estratigráfico, sedimentológico y paleontológico de los yacimientos con fósiles de vertebrados del Cretácico final de la Región Vasco-Cantábrica. Tesis doctoral, Universidad del País Vasco (UPV/EHU), Bilbao. 410 pp. (Unpublished).

Bonaparte, J.F. and Coria, R.A. 1993. Un nuevo y gigantesco sauropodo titanosaurio de la Formación Río Limay (Albiano-Cenomaniano) de la provincia del Neuquén, Argentina. Ameghiniana, 30(3), 271282.

Borsuk-Bialynicka, M. 1977. A new camarasaurid sauropod Opisthocoelicaudia skarzynskii, gen. n. sp. n. from the Upper Cretaceous of Mongolia. Palaeontologica Polonica, 37, 45-64.

Calvo, J.O. and González Riga, B.J. 2003. Rinconsaurus caudamirus gen. et sp. nov., a new titanosaurid (Dinosauria, Sauropoda) from the Late Cretaceous of Patagonia, Argentina. Revista Geológica de Chile, 30(2), 333-353.

Calvo, J.O., Porfiri, J.D., González-Riga, B.J., and Kellner, A.W.A. 2007. A new Cretaceous terrestrial ecosystem from Gondwana with the description of a new sauropod dinosaur. Anais da Academia Brasileira de Ciências, 79(3), 529-541.

Campione, N.E. and Evans, D.C., 2012. A universal scaling relationship between body mass and proximal limb bone dimensions in quadrupedal terrestrial tetrapods. BMC Biology, 10(1), 60. 
Canudo, J.I., Royo-Torres, R., and Cuenca-Bescós, G. 2008. A new sauropod: Tastavinsaurus sanzi gen. et sp. nov. from the Early Cretaceous (Aptian) of Spain. Journal of Vertebrate Paleontology, 28, 712-731.

Company, J. 2011. Bone histology of the titanosaur Lirainosaurus astibiae (Dinosauria: Sauropoda) from the Latest Cretaceous of Spain. Naturwissenschaften, 98(1), 67-78.

Company, J., Pereda Suberbiola, X., and RuizOmeñaca, J.I. 2009. Nuevos restos fósiles del dinosaurio Lirainosaurus (Sauropoda, Titanosauria) en el Cretácico Superior (Campaniano-Maastrichtiano) de la Península Ibérica. Ameghiniana, 46(2), 391-405.

Csiki, Z., Codrea, V., Jipa-Murzea, C., and Godefroit, P. 2010. A partial titanosaur (Sauropoda, Dinosauria) skeleton from the Maastrichtian of Nălaţ-Vad, Haţeg, Basin, Romania. Neues Jahrbuch für Geologie und Paläontologie Abhandlungen, 258 (3), 297-324.

Curry Rogers, K. 2009. The postcranial osteology of Rapetosaurus krausei (Sauropoda: Titanosauria) from the Late Cretaceous of Madagascar. Journal of Vertebrate Paleontology, 29(4), 1046-1086.

D'Emic. 2012. The early evolution of titanosauriform sauropod dinosaurs. Zoological Journal of the Linnean Society, 166, 624-671.

D'Emic, M.D., Wilson, J.A., and Chaterjee, S. 2009. The titanosaur (Dinosauria: Sauropoda) osteoderm record: review and first definitive specimen from India. Journal of Vertebrate Paleontology, 29 (1), 165-177.

D’Emic, M.D., Wilson, J.A., and Williamson, T.E. 2011. A sauropod dinosaur pes from the latest Cretaceous of North America and the validity of Alamosaurus sanjuanensis (Sauropoda, Titanosauria). Journal of Vertebrate Paleontology, 31, 1072-1079.

Díez Díaz, V. 2013. Revisión del dinosaurio saurópodo Lirainosaurus astibiae (Titanosauria) del Cretácico superior de la Península Ibérica. Comparación con otros titanosaurios del suroeste de Europa. Hipótesis filogenética y paleobiogeográfica. Ph.D.dissertation, Universidad del País Vasco/EHU, Bilbao, 306 pp.

Díez Díaz, V., Pereda Suberbiola, X., and Sanz, J.L. 2011. Braincase anatomy of the sauropod dinosaur Lirainosaurus astibiae (Titanosauria) from the Late Cretaceous of the Iberian Peninsula. Acta Paleontologica Polonica, 56, 521-533.

Díez Díaz, V., Pereda Suberbiola, X., and Sanz, J.L. 2012. Juvenile and adult teeth of the titanosaurian dinosaur Lirainosaurus (Sauropoda) from the Late Cretaceous of Iberia. Geobios, 45, 265-274.

Díez Díaz, V., Pereda Suberbiola, X. and Sanz, J.L. 2013. The axial skeleton of the titanosaur Lirainosaurus astibiae (Dinosauria: Sauropoda) from the latest Cretaceous of Spain. Cretaceous Research, 43:145160.
Floquet, M. 1991. La plate-forme nord-castillane au crétacé supérieur (espagne). Arrière pays ibérique de la marge passive Basco-Cantabrique. Sédimentation et vie. Memoires Géologiques de l'Université de Dijon, 14, 1-925.

Garcia, G., Amico, S., Fournier, F., Thouand, E., and Valentin, X. 2010. A new Titanosaur genus (Dinosauria, Sauropoda) from the Late Cretaceous of southern France and its paleobiogeographic implications. Bulletin de la Société Géologique de France, 181, 269-277.

Gascó, F 2009. Sistemática y anatomía funcional de Losillasaurus giganteus Casanovas, Santafé and Sanz, 2001 (Turiasauria, Sauropoda). Universidad Autónoma de Madrid (UAM). 73p (Unpublished).

Gomani, E.M. 2005. Sauropod dinosaurs from the Early Cretaceous of Malawi, Africa. Palaeontologia Electronica, 8 (1.27A): 1-37.

González Riga, B.J., Previtera, E., and Pirrone, C.A. 2009. Malarguesaurus florenciae gen. et sp. nov., a new titanosauriform (Dinosauria, Sauropoda) from the Upper Cretaceous of Mendoza, Argentina. Cretaceous Research, 30, 135-148.

Hocknull, S.A., White, M.A., Tischler, T.R., Cook, A.G., Calleja, N.D., Sloan, T., and Elliott, D.A. 2009. New Mid-Cretaceous (Latest Albian) Dinosaurs from Winton, Queensland, Australia. PLoS ONE 4 (7): e6190. doi:10.1371/journal.pone.0006190

Huene, F.v. 1929. Los Saurisquios y Ornithisquios del Cretáceo Argentino. Anales del Museo La Plata, 2, 1196.

Kellner, A.W.A., de Campos, D.A., de Azevedo, S.A.K., Trotta, M.N.F., Henriques, D.D.R., Craik, M.M.T., and de Silva, H.P. 2006. On a new titanosaur sauropod from the Bauru Group, Late Cretaceous of Brazil. Boletim do Museo Nacional Nueva Serie, Geologia, Rio de Janeiro 74, 1-31.

Le Loeuff, J. 1992. Les vértébrés continentaux du Crétacé supérieur d'Europe: Paléoécologie, Biostratigraphie et Paleobiogéographie. Ph.D. dissertation. Mémoires des Sciences de la Terre, Université Pierre and Marie Curie, Paris VI, France, 92-93, 273 pp. (Unpublished).

Le Loeuff, J. 1995. Ampelosaurus atacis (nov. gen., nov. sp.) un nouveau Titanosauridae (Dinosauria, Sauropoda) du Crétacé supérieur de la Haute Vallée de l'Aude (France). Comptes Rendus de l'Académie des Sciences Paris, 321(Ila), 693-699.

Le Loeuff, J. 2005. Osteology of Ampelosaurus atacis (Titanosauria) from Southern France, p. 115-137. In Tidwell, V. and Carpenter, K. (eds.), Thunder-Lizards. The Sauropodomorph Dinosaurs. Indiana University Press, Bloomington.

Le Loeuff, J., Buffetaut, E., Cavin, L., Martin, M., Martin, V., and Tong, H., 1994. An armoured titanosaurid sauropod from the Late Cretaceous of Southern France and the occurrence of osteoderms in the Titanosauridae. Gaia, 10:155-159. 
Mannion, P.D. and Calvo, J.O. 2011. Anatomy of the basal titanosaur (Dinosauria, Sauropoda) Andesaurus delgadoi from the mid-Cretaceous (Albian-early Cenomanian) Río Limay Formation, Neuquén Province, Argentina: implications for titanosaur systematics. Zoological Journal of the Linnean Society, 163, 155-181.

Mannion, P.D. and Otero, A. 2012. A reappraisal of the Late Cretaceous Argentinean sauropod dinosaur Argyrosaurus superbus, with a description of a new titanosaur genus. Journal of Vertebrate Paleontology, 32(3), 614-638.

Mannion, P.D., Upchurch, P., Barnes, R.N., and Mateus, O. 2013. Osteology of the Late Jurassic Portuguese sauropod dinosaur Lusotitan atalaiensis (Macronaria) and the evolutionary history of basal titanosauriforms. Zoological Journal of the Linnean Society, 168, 98-206.

Marsh, O., 1878. Principal characters of American Jurassic dinosaurs. Pt. I. American Journal of Science, 3, 411-416.

Ortega, F., Pérez-García, A., 2009. Cf. Lirainosaurus sp. (Dinosauria: Titanosauria) en el Cretácico Superior de Sacedón (Guadalajara). Geogaceta 46, 87-90.

Ortega, F., Sanz, J.L., Díez Díaz, V., and Escaso, F. 2012. Armoured titanosaurs from the Upper Cretaceous of Lo Hueco (Cuenca, Spain). Fundamental!, 20:173-174.

Owen, R. 1842. Report on British fossil reptiles, part II. Report of the British Association for the Advancement of Science, 60-294.

Packard, G.C., Boardman, T.J., and Birchard, G.F. 2009. Allometric equations for predicting body mass in dinosaurs. Journal of Zoology, 279(1): 102-110.

Pereda Suberbiola, X., Astibia, H., Murelaga, X., Elorza, J.J., Gómez-Alday, J.J. 2000. Taphonomy of the Late Cretaceous dinosaur-bearing beds of the Laño Quarry (Iberian Peninsula). Palaeogeography, Palaeoclimatology, Palaeoecology, 157, 247-275.

Powell, J.E. 1992. Osteología de Saltasaurus loricatus (Sauropoda-Titanosauridae) del Cretácico Superior del Noroeste Argentino, p. 165-230. In Sanz, J.L. and Buscalioni, A.D. (eds.), Los Dinosaurios y su entorno biótico. Actas del Segundo Curso de Paleontología de Cuenca-Instituto "Juan De Valdés," Cuenca.

Powell, J.E. 2003. Revision of South American titanosaurid dinosaurs: palaeobiological, palaeobiogeographical and phylogenetic aspects. Records of the Queen Victoria Museum, 111, 1-173.

Salgado, L. and Azpilicueta, C. 2000. Un nuevo saltasaurino (Sauropoda, Titanosauridae) de la provincia de Río Negro (Formacíon Allen, Cretácico Superior), Patagonia, Argentina. Ameghiniana, 37, 259-264.
Salgado, L., Coria, R.A., and Calvo, J.O. 1997. Evolution of titanosaurid sauropods I: Phylogenetic analysis based on the postcranial evidence. Ameghiniana, 34(1), 3-32.

Sanz, J.L., Powell, J.E, Le Loeuff, J., Martínez, R., and Pereda Suberbiola, X. 1999. Sauropod remains from the Upper Cretaceous of Laño (North-central Spain). Titanosaur phylogenetic relationships. Estudios del Museo de Ciencias Naturales de Álava, 14 (Número Especial 1), 235-255.

Seebacher, F. 2001. A New Method to Calculate Allometric Length-Mass Relationships of Dinosaurs. Journal of Vertebrate Paleontology, 21 (1). 51-60.

Seeley, H.G., 1887. On the classification of the fossil animals commonly called Dinosauria. Proceedings of the Royal Society London 43 (printed 1888), 165171.

Upchurch, P. and Martin, J. 2003. The anatomy and taxonomy of Cetiosaurus (Saurischia, Sauropoda) from the Middle Jurassic of England. Journal of Vertebrate Paleontology, 23(1), 208-231.

Upchurch, P., Barrett, P., and Dodson, P. 2004. Sauropoda, p. 259-324. In Weishampel, D.B., Dodson, P., and Osmólska, H. (Eds.), The Dinosauria. Second ed. University of California Press, Berkeley.

Vila, B., Galobart, À., Canudo, I., Le Loeuff, J., DinarèsTurell, J., Riera, V., Oms, O., Tortosa, T., and Gaete, R. 2012. The diversity of sauropod dinosaurs and their first taxonomic succession from the latest Cretaceous of southwestern Europe: Clues to demise and extinction. Palaeogeography, Palaeoclimatology, Palaeoecology. 350-352, 19-38.

Wilson, J.A. 2002. Sauropod dinosaur phylogeny: critique and cladistic analysis. Zoological Journal of the Linnean Society, 136, 217-276.

Wilson, J.A. 2006. Anatomical nomenclature of fossil vertebrates: standardized terms or 'lingua franca'? Journal of Vertebrate Paleontology, 26(3), 511-518.

Wilson, J.A. and Carrano, M.T. 1999. Titanosaurs and the origin of "wide-gauge" trackways: a biomechanical and systematic perspective on sauropod locomotion. Paleobiology, 25, 252-267.

Wilson, J.A. and Sereno, P.C. 1998. Early evolution and higher-level phylogeny of sauropod dinosaurs. Journal of Vertebrate Palaeontology, 18 (suppl. to 2), 168 (Society of Vertebrate Paleontology, Memoir 5).

Wilson, J.A. and Upchurch, P. 2003. A revision of Titanosaurus Lydekker (Dinosauria-Sauropoda), the first dinosaur genus with a "Gondwanan" distribution. Journal of Systematic Palaeontology, 1, 125-160.

Wilson, J.A., Barrett, P.M., and Carrano, M.T. 2011. An associated partial skeleton of Jainosaurus cf. septentrionalis (Dinosauria: Sauropoda) from the late Cretaceous of Chota Simla, Central India. Palaeontology, 54, 981-998. 